\title{
Exploring the potential of human adipocytes in periodontal regeneration: A review
}

\author{
Rebicca Ranjit $^{1 *}$, Pratik Manandhar ${ }^{2}$, Soni Bista ${ }^{1}$ \\ 'Dept. Of Periodontology and Oral Implantology, ${ }^{2}$ Dept. Of Prosthodontics and Maxillofacial prosthetics, \\ Gandaki Medical College Teaching Hospital and Research Center Pvt. Ltd. Pokhara, Nepal
}

\begin{abstract}
Stem cells, initially identified in embryonic tissues and later in numerous adult tissues, tend to possess the potentiality to differentiate into various cell types. Though most flexible of all stem cell lines, ethical issues restrict the use of embryonic cells. Furthermore, induced pluripotent stem cells (iPS) and adult stem cells (e.g: bone marrow stroma) can also be used. However, procurement of autologous bone marrow has its potential limitations. An alternate source of autologous adult stem cells which can be procured in large quantities, under local anesthesia, with minimal discomfort would be of keen interest. In the present context, human adult adipose tissue may be the best appropriate alternative source of mesenchymal stem cells. Studies have shown that adipose stem cells (ASCs) extracted from subcutaneous human adult adipose tissue tend to contain heterogeneous cell population called stromal vascular fraction (SVF). It may be used directly or cultured in for selection and expansion of an adherent population, and hence, they are called ASCs. The adipose tissue, obtained by suction-assisted lipectomy (i.e., liposuction), are processed to obtain a fibroblast-like population of cells, also called processed lipoaspirate (PLA). PLA cells has the potentiality to differentiate in vitro into adipogenic, chondrogenic, myogenic, and osteogenic cells in the presence of lineage-specific induction factors. This attributable feature of ASCs may be of significant importance in future clinical cell-based therapy for periodontal disease as well. This review describes current knowledge \& recent advances in ASCs \& their application. This review describes current knowledge and recent advances in ASCs and their application in periodontal regeneration.
\end{abstract}

KEYWORDS: Adipose-derived stem cells, Periodontal disease, Processed lipoaspirate, Stem cells, Stromal vascular fraction, Tissue engineering.

\section{Correspondence to:}

Dr. Rebicca Ranjit

Lecturer, Dept. Of Periodontology and Oral

Implantology

Gandaki Medical College Teaching Hospital and

Research Center Pvt. Ltd.Pokhara, Nepal

E-mail: rebiranjit@gmail.com

Submitted: $2^{\text {th }}$ March 2020

Accepted: $13^{\text {th }}$ June 2020

To cite: Ranjit $\mathrm{R}$, Manandhar $\mathrm{P}$, Bista S. Exploring the potential of human adipocytes in periodontal regeneration: A review. JGMC Nepal. 2020;13(1):68-77

DOI: $10.3126 /$ jgmcn.v13i1.28370

\section{INTRODUCTION}

Periodontal disease is a chronic inflammatory condition of the supporting structures characterized by persistent inflammation, connective tissue breakdown, and alveolar bone destruction. If left untreated, it continues with progressive alveolar bone destruction, leading to increased tooth mobility \& subsequent tooth loss. One of the major goals of periodontal therapy is to obtain regeneration of the affected tissues to their original architecture \& function.

Several procedures have been developed to achieve periodontal regeneration, including root surface conditioning, $^{1-3}$ bone graft placement, ${ }^{3-5}$ guided tissue regeneration, ${ }^{1,3,5,-7}$ enamel matrix derivatives ${ }^{8-10}$ \& growth factors ${ }^{11}$ application. However, these procedures used alone or in combination have limitations in obtaining a predictable outcome, especially in cases of advanced periodontal breakdown. So, recent advances in regenerative medicine \&stem cell biology have provided the opportunities for tissue engineering \& gene-based approaches in periodontal therapy.

Multilineage stem cells have substantial therapeutic potential 
for applications in tissue engineering \& gene therapy. Potent stem cells widely useful for these applications are: embryonic stem cells ${ }^{12}$ (ESCs), induced pluripotent stem cells (iPS) ${ }^{13,14} \&$ autologous stem cells. ${ }^{15}$ Although they seem to be appealing due to their pluripotentiality, their practical use is limited due to the potential problems of cell regulation \& ethical considerations. The autologous stem cells obtained from bone marrow have proven experimentally promising but its procurement is a major issue. Studies have shown that a population of stem cells can be isolated from human adipose tissue. ${ }^{16}$ Subpopulation of fibroblasts present within the fat tissues can be processed to obtain the processed lipoaspirates (PLA). These PLA cells, in vitro, can potentially differentiate into adipogenic, ${ }^{17,18}$ chondrogenic, ${ }^{18-21}$ myogenic ${ }^{22,23}$ \&osteogenic cells ${ }^{18,19,24-26}$ in the presence of lineage-specific induction factors. The evidences have suggested that the periodontal microenvironment may induce ADMPC (Adipose-derived multilineage progenitor cells) to differentiate into periodontal tissues and that the ADMPC themselves might secrete various factors that stimulate resident progenitor cells. ${ }^{27}$ These unique properties make ADMPC an important cell source for stem cell-based therapeutic approaches in the field of periodontology. The effect of autologous mesenchymal stem cells transplantation has been investigated in clinical trials for periodontal regeneration of healthy patients. ${ }^{28}$ This review study discusses the potential use of adipose-derived stem cells in the field of periodontal regeneration.

Isolation of adipocytes-derived stem cells: Rodbell \& colleagues in the 1960s pioneered the methods to isolate cells from adipose tissue using a rat. ${ }^{29-31} \mathrm{~A}$ study was done by Tobita et al, 2007 in Wistar rat in which control group was passed platelet rich plasma (PRP) only \& cases group were passed with adipocyte stem cells \& PRP. ${ }^{32}$ This study showed that after two to four weeks of implantation, a small amount of alveolar bone regeneration was observed \& eight weeks after implantation, periodontal ligament like structure was observed along with the alveolar bone. Human studies were also done by several groups. ${ }^{33-34}$ Different progenitor cells were successfully isolated and characterized from human orbital adipose tissue. ${ }^{35}$

Obtaining the adipose tissues: Adipose tissue is harvested by liposuction procedure. Under local anesthesia, around $1 \mathrm{~cm}$ incision is given, through which a hollow blunttipped cannula is inserted into subcutaneous space. The cannula is connected externally to a gentle suction which mechanically disrupts fat tissue \&draws them out from the adipose compartment. In order to minimize the blood loss \& contamination of tissue by peripheral blood cells, a solution of saline \& epinephrine is infused into adipose compartment. ${ }^{36}$ In this way, raw lipoaspirate $(\sim 300 \mathrm{cc})$ is obtained. ${ }^{16}$

Processing of raw lipoaspirate: When preserved at room temperature, the aspirated fat should be processed as quickly as possible. It can be stored or transported overnight without adipose-derived stem cell yield loss or changes in biological properties if it is preserved at $4{ }^{0} \mathrm{C} .{ }^{37}$ The obtained raw lipoaspirate is extensively washed with equal volume of phosphate buffered saline(PBS). The extracellular matrix is then enzymatically digested at $37^{\circ} \mathrm{C}$ for 30 min with $0.0075 \%$ collagenase ${ }^{16}$ or 40 min with $0.1 \%$ collagenase. $^{33}$ This enzymatic activity is neutralized with Dulbecco's modified Eagle's medium (DMEM), containing $10 \%$ FBS(Fetal Bovine Serum) \& the cell suspension is centrifuged at $1200 \mathrm{xg}$ for 10 minutes to isolate stromal vascular cells (SVC) ${ }^{38,39}$ pellets from primary adipocytes.

Obtaining processed lipoaspirates: SVF pellet is resuspended in basal medium containing $10 \%$ fetal bovine serum $^{40}$ or in $160 \mathrm{mM} \mathrm{NH}_{4} \mathrm{Cl} \&$ incubated at room temperature for 10 minutes to lyse the contaminating red blood cells. ${ }^{16}$ The cell suspension is then filtered through $100 \mu \mathrm{m}$ cell strainer / nylon mesh to remove cellular debris. The cells are plated \& incubated at $37^{\circ} \mathrm{C}$ / $5 \% \mathrm{CO}_{2}$ in control medium. The plates are then washed extensively with PBS to remove residual non-adherent RBCs. The medium should be changed in every second day till the cells reach $80-90 \%$ confluence. The cells were maintained at subconfluent levels in order to prevent their spontaneous differentiation. In this way, a large number of ASCs can be harvested approximately 2,50,000 cells per gram of tissue. ${ }^{41,42}$ Furthermore, the use of PRP augments the proliferation of human ASCs. ${ }^{32}$ ASCs can be successfully stored for more than six months which ensures the availability of autologous banked ASCs for clinical applications in the future..$^{43,44}$

\section{Characterisation of adipocytes stem cells:}

\section{1) Indirect immunoflourescence of PLA cells:}

It uses two antibodies; the unlabeled first (primary) antibody specifically binds with the target molecule, and the secondary antibody, that carries the fluorophore, recognizes the primary antibody and binds to it. PLA cells are then processed by using monoclonal antibodies to specific CD markers and lineage-specific protein. The cells are plated onto glass chamber slides, fixed in 4\% paraformaldehyde in 100 mM Na ${ }_{3} \mathrm{PO}_{4}$ buffer ( $\mathrm{pH} 7.0$ ) for $15 \mathrm{~min} .{ }^{16}$ The cells are then extensively washed for $10 \mathrm{~min}$ in $100 \mathrm{mM}$ glycine in PBS (PBS/glycine) \& blocked for one hour in 
immunofluorescent blocking buffer (IBB) that contains $5 \%$ bovine serum albumin (BSA), 10\% FBS, $1 \times$ PBS, $0.1 \%$ Triton $\mathrm{X}-100$ ) followed by incubation for one hour in IBB containing the following cell-specific monoclonal antibodies:

(1) Anti-smooth muscle actin: -To identify smooth muscle cells \& pericytes.

(2) Anti-Factor VIII:- To identify endothelial cells.

(3) ASO2:- To identify fibroblasts \& cells of mesenchymal origin.

The cells are again washed with PBS/glycine \& incubated for one hour in IBB containing a fluoroisothiocyanate (FITC)-conjugated secondary antibody mounted with a solution containing DAPI(diamidino-2-phenylindole) to detect the nuclei.

\section{2) Spectrophotometric assays:}

a) Alkaline Phosphatase (AP): Samples of PLA cells are placed in osteogenic medium (OM) for aroundsix weeks followed by washing with PBS. AP enzyme activity is then assayed using a commercial AP enzyme kit according to the method of Beresford et $\mathrm{al}(1986) .^{45} \mathrm{AP}$ activity is expressed as nanomoles of p-nitrophenol produced per minute per microgram of protein.

b) Total Calcium: PLA cells are placed in osteogenic medium for six weeks, then washed with PBS $\left(\mathrm{no} \mathrm{Ca}^{++}\right.$ or $\mathrm{Mg}^{++}$), harvested \& extracted in $0.1 \mathrm{~N} \mathrm{HCl}$ at $4^{\circ} \mathrm{C}$ for around four hours \& lastly centrifuged for five minutes at $10,000 \times \mathrm{g}$. A commercial kit is used to determine total calcium (millimolar $\mathrm{Ca}^{++}$per microgram of protein) in the supernatant. ${ }^{46}$

c) Dimethyldimethylene Blue: High-density micromass protocol is employed to differentiate PLA cells inchondrogenic medium (CM) for three weeks. ${ }^{47}$ With the help of an established method, ${ }^{48}$ PLA nodules are harvested $\&$ assayed for sulfated proteoglycans.

3) Cell Senescence Assay: The existence of senescenceassociated $\beta$-galactosidase (SA- $\beta$-gal or SABG) was proposed in 1995 by Dimri et $\mathrm{al}^{49}$ following the observation that when $\beta$-galactosidase assays are carried out at $\mathrm{pH} 6.0$, only cells in senescence state develop staining \& not the proliferating cells. It is a hypothetical hydrolase enzyme which helps in catalyzingthe hydrolysis of $\beta$-galactosides into monosaccharides in senescent cells. Cells from each culture passage (passage 1 to passage $15)$ are fixed for five minutes in $2 \%$ formaldehyde/ glutaraldehyde and incubated in a $\beta$-Gal reaction buffer (containing $1 \mathrm{mg} / \mathrm{ml} \mathrm{X-Gal,} 40 \mathrm{mM}$ citric acid/sodium phosphate buffer ( $\mathrm{pH} 6.0$ ), $5 \mathrm{mM}$ each of potassium ferrocyanide and potassium ferricyanide, $150 \mathrm{mM} \mathrm{NaCl}$, and $2 \mathrm{mM}\left(\mathrm{MgCl}_{2}\right)$.Senescent cells (blue) are identified by light microscopy.

4) Flow Cytometry: Flow cytometry helps in analyzing light scatter which distinguishes different cells based on their size, shape, \& internal complexity. The antibodies or ligands conjugated with fluorescent probes are used to measure the presence and amount of specific intracellular and cell surface molecules. Similarly, fluorescent indicators help in measuring the transport of ions across the cellular membranes, as well as assess the mitochondrial activity \& other metabolic parameters. PLA samples are cultured in control medium 72 hours before analysis \& then flow cytometry with a FAC scan argon laser cytometer is performed. Briefly, cells are harvested in $0.25 \%$ trypsin/EDTA \& are fixed in ice-cold $2 \%$ formaldehyde for $30 \mathrm{~min}$. The fixed cells are then washed in the buffer solution (PBS, 2\% FBS, 0.2\%Tween-20) \& then incubated for 30 min inflow cytometry buffer containing fluorescein isothiocyanateconjugated monoclonal antibodies to $\mathrm{SH}_{3}$, STRO-1, and the CD antigens: $13,14,16,31,34,44,45,49 d, 56,62 \mathrm{e}$, $71,90,104,105$, and 106. PLA cells are stained with a phycoerythrin-conjugated nonspecific IgG to assess background fluorescence.

\section{Multilineage differentiation potential of PLA cells:}

PLA cells possess adipogenic, chondrogenic, osteogenic, myogenic \& neurogenic lineages depending upon their cultured in specific induction media (Table 1). ${ }^{16}$ DMEM is used for differentiation into all the cell types.

\section{Table 1. Lineage-specific differentiation}

\begin{tabular}{|c|c|c|}
\hline Medium & Serum & Supplementation \\
\hline Control & $10 \%$ FBS & None \\
\hline $\begin{array}{l}\text { Adipogenic } \\
\text { (AM) }\end{array}$ & $10 \%$ FBS & $\begin{array}{l}0.5 \mathrm{mM} \text { isobutyl-methylxanthine (IBMX), } 1 \\
\mu \mathrm{M} \text { dexamethasone, } 10 \mu \mathrm{M} \text { insulin, } 200 \mu \mathrm{M} \\
\text { indomethacin, } 1 \% \text { antibiotic/ antimycotic }\end{array}$ \\
\hline $\begin{array}{l}\text { Myogenic } \\
\text { (MM) }\end{array}$ & $\begin{array}{l}10 \% \text { FBS, } \\
5 \% \text { HS }\end{array}$ & $\begin{array}{c}0.1 \mu \mathrm{M} \text { dexamethasone, } 50 \mu \mathrm{M} \text { hydrocortisone, } \\
1 \% \text { antibiotic/ antimycotic }\end{array}$ \\
\hline $\begin{array}{l}\text { Chondrogenic } \\
\text { (CM) }\end{array}$ & $1 \%$ FBS & $\begin{array}{l}6.25 \mathrm{mg} / \mathrm{ml} \text { insulin, } 10 \mathrm{ng} / \mathrm{ml} \text { TGF- } \beta_{1}, 50 \\
\mathrm{nM} \text { ascorbate-2-phosphate, } 1 \% \text { antibiotic/ } \\
\text { antimycotic }\end{array}$ \\
\hline $\begin{array}{l}\text { Osteogenic } \\
\quad(\mathrm{OM})\end{array}$ & $10 \%$ FBS & $\begin{array}{c}0.1 \mu \mathrm{M} \text { dexamethasone, } 50 \mu \mathrm{M} \text { ascorbate-2- } \\
\text { phosphate, } 10 \mathrm{mM} \text { ß-glycerophosphate, } 1 \% \\
\text { antibiotic/ antimycotic }\end{array}$ \\
\hline
\end{tabular}


Table 2. Markers and assays of lineage -specific differentiation

\begin{tabular}{|c|c|c|}
\hline Lineage & Serum & Lineage-specific determinant \\
\hline Adipogenic & $10 \% \mathrm{FBS}$ & Lipid accumulation \\
\hline & 1. Phase contrast microscopy & 1. Multinucleation \\
\hline Myogenic & $\begin{array}{l}\text { 2. Myosin- and MyoD1-specific } \\
\text { and MyoD1 expression mono- } \\
\text { clonal antibodies }\end{array}$ & $\begin{array}{l}\text { 2. Skeletal muscle myosin } \\
\text { heavy-chain }\end{array}$ \\
\hline \multirow{2}{*}{$\begin{array}{l}\text { Chondro- } \\
\text { genic }\end{array}$} & \multirow{2}{*}{$\begin{array}{l}\text { 1. Alcian Blue (pH 1.0) stain } \\
\text { 2. Collagen II-specific mono- } \\
\text { clonal antibody }\end{array}$} & $\begin{array}{l}\text { 1. Sulfated proteoglycan- rich } \\
\text { matrix }\end{array}$ \\
\hline & & 2. Collagen II synthesis \\
\hline \multirow{2}{*}{ Osteogenic } & 1. AP stain & 1. AP activity \\
\hline & 2. Von Kossa stain & 2. Calcified matrix production \\
\hline
\end{tabular}

\section{Adipogenesis:}

\section{Adipogenic inductive compounds (Table 1):}

a) Glucocorticoid receptor ligands (dexamethasone),

b) Insulin,

c) Biotin,

d) d-pantothenate,

e) Cyclic AMP agonist (forskolin) \&

f) Equivalent Peroxisome proliferator activated receptor gamma agonist (PPAR $\gamma$ )

In response to these adipogenic induction medium, ASCs tend to differentiate into adipocytes. ${ }^{16,50-52}$ Within two weeks after placing in adipogenic medium, the ASC contain vacuoles filled with neutral lipid cells. The cells are fixed at room temperature in $4 \%$ formaldehyde/ $1 \%$ calcium for 60 minutes, washed with $70 \%$ ethanol, incubated in $2 \%$ (wt/vol) Oil Red 0 reagent for five minutes at room temperature. Oil Red 0 stain (Table 2) is used to stain intracellular lipid droplets accumulation. ${ }^{53}$ Excessive stain are removed by washing with $70 \%$ ethanol \& counterstaining is done with hematoxylin for two minutes. ASCs tend to undergo morphological changes \& reduce their proliferation rate during the differentiation. During differentiation, parameters including leptin, adipogenic mRNA like fatty acid binding protein, aP2 mRNA levels are increased by several hundred-fold. ${ }^{51,54,55}$

\section{Clinical implication:}

i. Replacement of adipose tissue

ii. Replacement in large soft tissue defects formed due to trauma, burns \& oncological resections.

\section{Chondrogenesis:}

Chondrogenic induction medium (Table 1):16, 21, 56
a) Ascorbate,
b) Dexamethasone
c) Transforming growth factor- $\beta$

ASCs cells are incubated for three weeks in DMEM containing $1 \%$ FBS, 40mg/ml proline, $100 \mathrm{mg} / \mathrm{ml}$ pyruvate, $50 \mathrm{mM}$ L-ascorbic acid-2-phosphate, $10 \mathrm{ng} /$ mltransforming growth factor-b3. ${ }^{57}$ The cells are then fixed for one hour with 4\% paraformaldehyde \& rinsed with PBS. After induction, cell condensation occurs followed by ridge spheroid/nodule formation by two days. Chondrogenesis is confirmed using the histologic stain Alcian Blue (Table 2) at acidic $\mathrm{pH}$ (one\& below) (pH 2.5, Wako) which stains sulfated proteoglycans present in cartilagenous matrices. Quantitation of sulfated proteoglycan levels revealed a time-dependent increase in cartilage-induced PLA cells upto two weeks of induction, followed by a slight decrease at three weeks. Expression of aggrecan, chondroitin sulphate, cartilagenous collagen type II \& IV isoformsare suggestive of chondrogenesis. Standard hematoxylin and eosin staining are used to assess cellular morphological features of the processed lipoaspirate cell nodules (paraffin sections), \& the presence of collagens was confirmed with Goldner's trichrome stain.

\section{Clinical implication:}

i. Envisioning the therapies that facilitate cartilage repair ii. Substantial cartilage remodeling and repair

Osteogenesis: Osteogenic induction medium (Table 1): a) Ascorbate, b) $\beta$-glycerophosphate, c) Dexamethasone d) Vitamin D3.

ASCs cells are incubated for three weeks in DMEM containing 10\% FBS, $100 \mathrm{nM}$ dexamethasone, $10 \mathrm{mM}$ $\beta$-glycerophosphate and $50 \mu \mathrm{M}$ L-ascorbic acid-2phosphate.After fixation cells are incubated with $0.16 \%$ naphthol AS-TR phosphate and $0.8 \%$ Fast Blue BB dissolved in $0.1 \mathrm{M}$ Tris buffer ( $\mathrm{pH} 9.0$ ) for one hour at $37^{\circ} \mathrm{C}$. For osteogenic differentiation, cells were also incubated in $1 \%$ alizarin red $\mathrm{S}$ for three minutes to detect calcium deposition. ${ }^{58}$ In order to assess osteogenesis, levels of AP enzyme activity is determined by alkaline phosphatase stain \&extracellular matrix calcification is quantitated by Von Kossa staining. To detect AP activity, cells are incubated in osteogenic medium for two weeks, rinsed with PBS, \& stained with a $1 \%$ AP solution (1\% naphthol ABSI phosphate, $1 \mathrm{mg} / \mathrm{mL}$ Fast Red TR) at $37^{\circ} \mathrm{C}$ for $30 \mathrm{~min}$. For Von Kossa staining (Table 2), the cells are incubated in OM for four weeks, fixed with $4 \%$ paraformaldehyde for $60 \mathrm{~min}$ at room temperature, rinsed with distilled water \&then overlaid with a $1 \%$ (wt/ vol) silver nitrate solution in the absence of light for 30 minutes. The cells are developed under UV light for 60 minutes \& finally counterstained with $0.1 \%$ eosin in ethanol. Expression of genes 
\& proteins associated with osteoblasts phenotypes such as osteopontin, osteonectin, osteocalcin, collagen type I, BMP2 and BMP-4, CBFA-1 are suggestive of osteogenic potential of adipocytes stem cells. ${ }^{16,54}$ The first case of autologous ASC use for osseous repair has been reported in the treatment of a calvarial defect in a seven-year-old girl. ${ }^{59} \mathrm{~A}$ study involved treatment of four patients possessing large cranial defects with a combination of ADSCs and b-tricalcium phosphate granules. Computed tomography scanning subsequently revealed improved ossification in all of the cases. ${ }^{60}$

\section{Myogenesis:}

A. Skeletal muscle: Skeletal muscle myogenic medium (MM) (Table 1):-
a) $0.1 \mathrm{mM}$ Dexamethasone,
b) $50 \mathrm{mM}$ Hydrocortisone,
c) $10 \% \mathrm{FBS}$
d) $5 \%$ Horse serum

PLA cells, when placed in myogenic medium (MM) for upto six weeks, result in the expression of the multiple myogenic transcription factor myod1, myosin, myf6, myf5 \& myogenin ${ }^{16,18}$ followed by fusion \& the formation of multinucleated cells that expressed the myosin heavy chain. ${ }^{61}$ The expression of myogenic transcription factors can be confirmed by immunohistochemical staining \&real time-PCR. Thus, skeletal myogenesis is peculiarized by a period of myoblast proliferation, followed by the expression of muscle-specific proteins and fusion to form multinucleated myotubules.

B. Smooth muscles: Smooth muscle inductive medium (Table 1):-

a) MCDB131 supplemented with 1\% FBS \&

b) $100 \mathrm{u} / \mathrm{ml}$ of heparin(for upto six weeks at $37^{\circ} \mathrm{C}$ with $5 \% \mathrm{CO}_{2}$ )

The expression of smooth muscle specific proteins like: smooth muscle actin (SMA), calponin, SM22, smoothelin, h-caldesmon \&smooth muscle myosin heavy chain (SMMHC) $^{62,63}$ are suggestive of myogenic potential of adipocytes stem cells. The smooth muscle differentiation has effect on cell size, shape, membrane potential, metabolic activity \& responsiveness to external signals.

Differentiated SMCs exhibit two specific phenotypes ${ }^{64}$ namely,

i. Synthetic \&proliferative

ii. Contractile and quiescent phenotype

Contractility is an important characteristic of SMCs which plays role in angiogenesis, blood vessel maintenance, \& mechanical regulation of hollow organs such as bladder. This property can be of value in the repair of smooth muscle defects in the gastrointestinal and urinary tracts..

Neurogenesis: Human ASCs also exhibit neuronal and/ or oligodendrocytic markers. The neurogenic induction medium include (Table 1):-DMEM enriched with $500 \mathrm{mM}$ IBMX, $200 \mathrm{mM}$ INDO, \& $5 \mathrm{mg} / \mathrm{ml}$ insulin for 1 hour. PLAs in neurogenic medium, when express neuronal markers like:S100, NF70, NSE,NeuN, MAP-2, nestin in addition to GFAP and GalC as markers of astrocytes and oligodendrocytes respectively, are suggestive of neurogenic potential of ASCs. It is still unclear that whether the transplanted cells replace the lost neurons or provide a supporting scaffold for existing stem cells and injured neurons. Specifically, these PLA cells undergo retraction,forming compact cell bodies with multiple extensions. Western blotting test confirms an increase in NSE protein upon induction while real time-PCR analysis confirms the expression of nestin. This sums up that the expression of nestin, NSE, \& NeuN, along with absence of choline acetyltransferase, myelinbasic protein, or GFAP expression, suggests that PLA cells may be capable of assuming an early neuronal or neural precursor phenotype.

\section{DISCUSSION}

The ultimate goal of the treatment of periodontal disease is the reorganization of functional tissues, predictable regeneration of the lost periodontal tissues and eventually achieving the periodontal health. The regeneration of periodontal tissue requires the restoration of cementum, periodontal ligament, and alveolar bone. ${ }^{65} \mathrm{~A}$ number of surgical regenerative techniques including osseous grafts, ${ }^{3-5}$ alloplast grafts, ${ }^{3}$ guided tissue regeneration (GTR) technique, ${ }^{1,3,5,6}$ enamel matrix proteins, ${ }^{8-10}$ chemical mediators, ${ }^{11}$ have been developed to regenerate the lost periodontal tissues. Although these treatment modalities have been widely accepted, the amount of tissue regenerated could not be well-predicted in cases of advanced periodontal defects. So, periodontal tissue regeneration with autologous stem cells (embryonic stem cells, iPS,bone marrow mesenchyme stem cells) was introduced for cell-based therapy in periodontal diseases. However, the procurement of such stem cells has its own potential limitations.

Till date, human adult adipose tissue may be the best suitable alternative source of mesenchyme stem cells which is obtainable in large quantities, under local anesthesia, with minimal site morbidity \& patient discomfort. This alternative source of autologous stem 
cells contain multilineage potential to differentiate towards the adipogenic, osteogenic, chondrogenic, neurogenic \& myogenic lineages with appropriate medium supplementation. Following induction, the differentiation to specific lineage can be assessed using histology \& immunohistochemistry.

Tissue-specific scaffolds (stable supporting structures), signalling systems \& vascularization are the major prerequisites for the differentiation of stem cells into the desired cells \& use them effectively to construct the threedimensional (3D) tissues. Various scaffolds that can be used are: - collagen I (excellent cellular compatibility), porous collagen bead (injectable cell delivery vehicles), placental dermal matrix, XLHA (hyaluronan sulphate) incorporated in placental dermal matrix, hyaluronic acid gel, HFIP silk fibroin chitosan scaffold, gelatin sponges, monofilament polypropylene, polyglycolic acid meshes etc. The autologous transplantation of MSCs in combination with tissue engineering, such as cell sheet technology, has been shown to be effective for regeneration of the periodontium..$^{66,67}$

A histological analysis after injection of ASCs+PRP admixture into periodontal defect showed a small amount of alveolar bone regeneration at $2^{\text {nd }} \& 4^{\text {th }}$ weeks of implantation and a periodontal ligament-like structure at $8^{\text {th }}$ weeks. ${ }^{32}$ The effect of autologous MSC transplantation has been investigated in clinical trials for periodontal regeneration of healthy patients. ${ }^{28,68}$ Some studies have shown that the periodontal microenvironment induces ADMPC to secrete various factors that stimulate resident progenitor cells to differentiate into periodontal tissues. ${ }^{27}$

Although many clinical trials have demonstrated the efficacy of autologous MSC transplantation, their clinical application is limited by age restrictions, tissue quality and systemic diseases (such as diabetes mellitus, rheumatoid arthritis, systemic lupus erythematosus), which alters the intrinsic properties of MSCs and also increase the difficulty of isolating MSCs. ${ }^{69}$ Efficient use of allogeneic MSCs may be an alternative strategy that overcomes the limitations of autologous MSC transplantation procedures for the regeneration of large periodontal defects.

In recent years, evidence has supported periodontal regeneration by allogeneic MSC transplantation in periodontal defects using animal models. ${ }^{70}$ Bonemorphometric analysis following the allogeneic transplantation of ADMPC in a micro-mini pig periodontal defect model showed a significant amount of bone regeneration ability. The histologic analysis showed a comparable regeneration potentiality of ADMPC by allogenicc transplantation as compared to those of autologous transplantation. These results indicate that ADMPC have immune-modulation capability that can induce periodontal tissue regeneration by allogeneic transplantation. ${ }^{65}$

\section{CONCLUSION}

The future of engineering the mesodermally derived tissues from stem cells is very promising \& it definitely requires a readily available source of donor cells. Although further characterization of the PLA cells within adipose tissue is necessary, the results obtained from large number of studies suggest that adipose tissue may be another potent source of pluripotent stem cells with multiple germline potential.

\section{REFERENCES}

1) Caffesse RG, Nasjleti CE, Anderson GB, Lopatin DE, Smith BA, Morrison EC. Periodontal healing following guided tissue regeneration with citric acid \& fibronectin application. J Periodontol. 1991 ;62(1):21-9. DOI: 10.1902/jop.1991.62.1.21

2) Caffesse RG, Smith BA, Nasjleti CE,Lopatin DE. Cell proliferation after flap surgery, root conditioning and fibronectin application. J Periodontol.1987 Oct;58(10):661-6. DOI: 10.1902/jop. 1987.58.10.661 PMID:3312566.

3) Schallhorn RG, McClain PK. Combined osseous composite grafting, root conditioning, and guided tissue regeneration. Int $\mathrm{J}$ Periodontics Restorative Dent.1988;8(4):8-31.

4) Gantes B, Martin M, Garrett S, Egelberg J. Treatment of periodontal defects (II). Bone regeneration in mandibular classII defect.J Clin Periodontol.1988 Apr;15(4):232-9. DOI: 10.1111/j.1600-051x.1988. tb01576.x PMID:3290277.

5) Camelo M, Nevins ML, Schenk RK,Simion M, Rasperini $\mathrm{G}$, Lynch SE, et al. Clinical, radiographic and histologic evaluation of human periodontal defects treated with Bio-Oss and Bio-Gide. Int J Periodontics Restorative Dent. 1998 Aug;18(4):321-31.

6) Nyman S, Lindhe J, Karring $T$, Rylander H. New attachment following surgical treatment of human periodontal disease. J Clin Periodontol.1982 Aug;9(4):290-6. DOI: $10.1111 /$ j.1600051X.1982.tb02095.x PMID:6964676.

7) Lindhe J, Pontoriero R, Berglundh Taraujo M. The effect of flap management and bioresorbable occlusive devices in GTR treatment of degree III furcation defects. 
An experimental study in dogs.J Clin Periodontol. 1995 Apr;22(4):276-83. DOI: 10.1111/j.1600-051x.1995. tb00148.x PMID: 7622633.

8) Yukna RA, Mellonig JT. Histologic evaluation of periodontal healing in humans following regenerative therapy with enamel matrix derivative: a 10-case series. J Periodontol. 2000 May;71(5):752-9. DOI: 10.1902/jop.2000.71.5.752 PMID:10872956.

9) Mellonig JT: Enamel matrix derivative for periodontal reconstructive surgery: technique and clinical and histologic case report. Int J Periodontics Restorative Dent. 1999 Feb;19(1). PMID: 10379282.

10) Heijl L, Heden G, Svärdström G, Ostgren A. Enamel matrix derivative. J Clin Periodontol. 1997;24(9):70514. DOI: $10.1111 / \mathrm{j} .1600-051 \mathrm{X} .1997$. tb00253.x PMID:9310876.

11) Graves DT, Cochran DL. Mesenchymal cell growth factors, Crit Rev Oral Biol 1990 Jan;1(1):17-36. DOI: 10.1177/10454411900010010301 PMID:2101259.

12) Ahn HH, Lee JH, Kim KS, Lee JY, Kim MS, Khang G, et al. Polyethyleneimine-mediated gene delivery into human adipose derived stem cells. Biomaterials. 2008 May;29(15):2415-22. DOI: $10.1016 / \mathrm{j}$. biomaterials.2008.02.006 PMID:18295879.

13) Crisan M, Yap S, Casteilla L,Chen CW, Corselli M, Park $\mathrm{TS}$, et al. A perivascular origin for mesenchymal stem cells in multiple human organs. Cell Stem Cell.2008 Sep;3(3):301-13. DOI: 10.1016/j. stem.2008.07.003 PMID:18786417.

14) Parker A, Shang H, Khurgel M, Katz A. Low serum and serum-free culture of multipotential human adipose stem cells. Cytotherapy. 2007 Jan 1;9(7):637-46. DOI: 10.1080/14653240701508452 PMID:17917877.

15) Aoki T, Ohnishi H, Oda Y, Tadokoro M, Sasao M, Kato $\mathrm{H}$, et al. Generation of induced pluripotent stem cells from human adipose derived stem cells without c-MYC. Tissue Eng Part A. 2010 Mar;16(7):2197-206. DOI:10.1089/ten.tea.2009.0747PMID:20146561

16) Zuk PA, Zhu M, MizunoH, Huang J, Futrell JW, Katz AJ, et al. Multilineage cells from human adipose tissue: implications for cell based therapies. Tissue Eng. 2001 Apr;7(2):211-28. DOI: 10.1089/1076327013000628 59PMID:11304456.

17) Beresford JN, Bennett JH, Devlin C, Leboy PS, Owen ME. Evidence for an inverse relationship between the differentiation of adipocytic and osteogenic cells in rat marrow stromalcell cultures. J Cell Sci. 1992 Jun;102(2):341-51. PMID: 1400636.
18) Pittenger MF, Mackay AM, Beck SC, Jaiswal RK, Douglas R, Mosca JD, et al. Multilineage potential of adult human mesenchymal stem cells. Science. 1999 Apr;284(5411):143-7. DOI: 10.1126/ science.284.5411.143 PMID:10102814.

19) Caplan AI: Mesenchymal stem cells. J Orthop Res. 1991 Sep;9(5):641-50. DOI: 10.1002/ jor.1100090504PMID:1870029.

20) Yoo JU, Barthel TS, Nishimura K, Solchaga L, Caplan AI, Goldberg VM, et al. The chondrogenic potential of human bone-marrow-derived mesenchymal progenitor cells. J Bone Joint Surg Am. 1998 Dec;80(12):1745-57. DOI: 10.2106/00004623199812000-00004 PMID:9875932.

21) Huang JI, Zuk PA, Jones NF, Zhu M, Lorenz HP, Hedrick $\mathrm{MH}$, et al. Chondrogenic potential of multipotential cells from human adipose tissue. Plast Reconstr Surg. 2004 Feb;113(2):585-94. DOI: 10.1097/01. PRS.0000101063.27008.E1 PMID:14758221.

22) Wakitani S, Saito T, Caplan AI. Myogenic cells derived from rat bone marrow mesenchymal stem cells exposed to 5-azacytidine. Muscle Nerve. 1995 Dec;18(12):1417-26. DOI: 10.1002/mus.880181212 PMID:7477065.

23) Ferrari G, Cusella-De Angelis D, Coletta M, Paolucci E, Stornaiuolo A, Cossu G,et al. Muscle regeneration by bone marrow-derived myogenic progenitors. Science. 1998 Mar;279(5356):1528-30. DOI: 10.1126/science.279.53561528PMID:9488650.

24) Cheng SL, Yang JW, Rifas L, Zhang SF, Avioli LV. Differentiation of human bone marrow osteogenic stromal cells in vitro: induction of the osteoblast phenotype by dexamethasone. Endo. 1994 Jan;134(1):277-86. DOI: 10.1210/ endo.134.1.8275945 PMID:8275945.

25) Haynesworth SE, Goshima J, Goldberg VM, Caplan AI. Characterization of cells with osteogenic potential from human marrow. Bone. 1992 Dec;13(1):81-8. DOI: 10.1016/8756-3282(92)90364-3

26) Rickard DJ, Kassem M, Hefferan TE, Sarkar G, Spelsberg TC, Riggs BL. Isolation and characterization of osteoblast precursor cells from human bone marrow. J Bone Min Res. 1996 Mar;11(3):312-24. DOI: 10.1002/ jbmr.5650110305 PMID:8852942.

27) Lemaitre $M$, Monsarrat $P$, Blasco-Baque $V$, Loubières $\mathrm{P}$, Burcelin R, Casteilla L, et al. Periodontal Tissue Regeneration Using Syngeneic Adipose-Derived Stromal Cells in a Mouse Model. Stem cells translational medicine. 2017;6(2):656-665. DOI: 
10.5966/sctm.2016-0028 PMID: 28191762.

28) Chen FM, Gao LN, Tian BM, Zhang XY, Zhang YJ, Dong GY, et al. Treatment of periodontal intrabony defects using autologous periodontal ligament stem cells: a randomized clinical trial. Stem cell research \& therapy. 2016;7(1):33. DOI: 10.1186/s13287-016-02881 PMID: 29426367.

29) Rodbell M: Metabolism of isolated fat cells. II. The similar effects of phospholipase C (Clostridium perfringens alpha toxin) and of insulin on glucose and amino acid metabolism. J Biol Chem. 1966 Jan;241(1):130-9. PMID: 4379054.

30) Rodbell M: The metabolism of isolated fat cells. IV. Regulation of release of protein by lipolytic hormones and insulin. J Biol Chem. 1966 Sep;241(17):3909-17. PMID: 4288359.

31) Rodbell M, Jones AB. Metabolism of Isolated Fat Cells III. The similar inhibitory action of phospholipase C (Clostridium Perfringes $\alpha$ toxin) and of insulin on lipolysis stimulated by lipolytic hormones and theophylline. Journal of Biological Chemistry. 1966 Jan;241(1):140-2 PMID: 4285132.

32) Tobita M, Uysal AC, Ogawa R, Hyakusoku H, Mizuno H. Periodontal Tissue Regeneration with AdiposeDerived Stem Cells. Tiss Eng. 2007;00(00). DOI: 10.1089/ten.2007.0048

33) Deslex S, Negrel R, Vannier C, Etienne J, Ailhaud G. Differentiation of human adipocyte precursors in a chemically defined serum-free medium. Int J Obes. 1987;11(1):19-27. PMID: 3570635.

34) Engfeldt P, Arner P, Ostman J: Influence of adipocyte isolation by collagenase on phosphodiesterase activity and lipolysis in man J Lipid Res. 1980 May;21(4):4438. PMID: 6247409.

35) Ho JH, Ma WH, Tseng TC, Chen YF, Chen MH, Lee OK. Isolation and Characterization of Multi-Potent Stem Cells from Human Orbital Fat Tissues.Tiss Eng Part A. 2011 Jan;17(1-2):255-66. DOI: 10.1089/ten. TEA.2010.0106PMID:20726817.

36) Messagio F. Mesenchymal stem cells from human adipose tissue: Characterization and immunomodulatory properties of tissue and cellular products [dissertation]. Milano: Universita Degli Study Di Milano; 2012-2013. p 85.

37) Matsumoto D, Shigeura T, Sato $K$, Inoue $K$, Suga $H$, Kato $\mathrm{H}$, et al. Influences of preservation at various temperatures on liposuction aspirates. Plast Reconstr Surg. 2007;120(6):1510-7. DOI: 10.1097/01.
prs.0000288015.70922.e4PMID:18040181.

38) Hauner H, Schmid P, Pfeiffer EF. Glucocorticoids and insulin promote the differentiation of human adipocyte precursor cells into fat cells. J Clin Endocrinol Metabol. 1987 Apr;64(4):832-5. DOI: 10.1210/jcem-64-4-832 PMID:3546356.

39) Katz AJ, Llull R, Hedrick MH, Futrell JW. Emerging approaches to the tissue engineering of fat. Clin Plast Surg. 1999 Oct;26(4):587-603. PMID: 10553215.

40) Estes BT, Diekman BO, Guilak F. Monolayer cell expansion conditions affect the chondrogenic potential of adipose-derived stem cells.Biotechnol Bio Eng. 2008 Mar;99(4):986-95. DOI: 10.1002/bit.21662 PMID:17929321 PMCID:PMC3576028.

41) Aust L, Devlin B, Foster SJ, Halvorsen YD, Hicok K, du Laney $\mathrm{T}$, et al. Yield of human adipose-derived adult stem cells from liposuction aspirates. Cytotherapy. 2004;6(1):7-14.DOI: 10.1080/14653240310004539 PMID:14985162.

42) Guilak F, Estes BT, Diekman BO, Moutos FT, Gimble JM. Nicolas Andry Award: Multipotentadultstem cells from adipose tissue for musculoskeletal tissue engineering. Clin Orthop Relat Res. 2010 Sep;468(9):2530-40. DOI: $10.1007 / \mathrm{s} 11999-010-1410-9$ PMID:20625952 PMCID:PMC2919887.

43) De Rosa A, De Francesco F, Tirino V, Ferraro GA, Desiderio V, Paino F, et al. A new method for cryopreserving adipose derived stem cells: an attractive and suitable large-scale and long-term cell banking technology. Tissue Engineering Part C: Methods. 2009 Apr;15(4):659-67. DOI: 10.1089/ten. tec.2008.0674 PMID:19254116.

44) Gonda K, Shigeura T, Sato T,Matsumoto D, Suga $\mathrm{H}$, Inoue K, et al. Preserved proliferative capacity and multipotency of human adipose-derived stem cells after long-term cryopreservation. Plast Reconstruct Surg. 2008 Feb;121(2):401-10. DOI: 10.1097/01. prs.0000298322.70032.bc PMID:18300956.

45) Beresford JN, Gallagher JA, Russel RGG. 1, 25-Dihydroxyvitamin D3 and human bone-derived cells in vitro: effects on alkaline phosphatase, type I collagen and proliferation. Endocrinology. 1986 Oct;119(4):1776-85. DOI: 10.1210/endo-119-4-1776 PMID:3489608.

46) Zuk PA, Zhu M, Ashjian P, De Ugarte DA, Huang JI, Mizuno H, et al: Human adipose tissue is a source of multipotent stem cells. Mol Biol Cell. 2002 Dec;13(12):4279-95. DOI: 10.1091/mbc.e0202-0105PMID:12475952 PMCID:PMC138633. 
47) Reddi AH. Regulation of local differentiation of cartilage and bone by extracellular matrix: a cascade type mechanism. Prog Clin Biol Res. 1982;110 Pt B:261-268 PMID: 7167576.

48) Farndale RW, Buttle DJ, Barrett AJ. Improved quantitation and discrimination of sulfated glycosaminoglycans by use of dimethylmethylene blue. Biochimic Biophys Acta. 1986 Sep;883(2):1737. DOI: 10.1016/0304-4165(86)90306-5 PMID: 3091074.

49) Dimri GP, Lu X, Basile G, Ascota M, Scott G, Roskelley C, et al. A biomarker that identifies senescent human cells in culture and aging skin in vivo. Proc Natl Acad Sci U S A. 1995 Sep;92(20):9363-9367. DOI: 10.1073/ pnas.92.20.9363 PMID: 7568133.

50) Farmer SR: Transcriptional control of adipocyte formation. Cell Metab. 2006 Oct;4(4):263-73. DOI: 10.1016/j.cmet.2006.07.001 PMID:17011499.

51) Hauner H, Entenmann G, Wabitsch M, Gaillard D, Ailhaud G, Negrel R, et al: Promoting effect of glucocorticoids on the differentiation of human adipocyte precursor cells cultured in a chemically defined medium. J Clin Invest. 1989 Nov;84(5):16631670.DOI: 10.1172/JCI114345 PMID:2681273.

52) Lazar MA.PPARgamma,10years later. Biochimie. 2005 Jan;87(1):9-13.DOI: 10.1016/j.biochi.2004.10.021 PMID:15733730.

53) Preece A: A Manual for Histologic Technicians. Boston, MA: Little, Brown and Co. 1972.

54) Halvorsen YD, Bond A, Sen A, Franklin DM, LeaCurrie YR, Sujkowski D, et al: Thiazolidinediones and glucocorticoids synergistically induce differentiation of human adipose tissue stromal cells: biochemical, cellular, and molecular analysis. Metabolism. 2001 Apr;50(4):407-13. DOI: 10.1053/meta.2001.21690 PMID:11288034.

55) Sen A, Lea-Currie YR, Sujkowska D, Franklin DM, Wilkison WO, Halvorsen YD, et al: Adipogenic potential of human adipose derived stromal cells from multiple donors is heterogeneous. J Cell Biochem. 2001 May;81(2):312-9. DOI: 10.1002/1097-4644(20010501)81:2<312::aidjcb1046>3.0.co;2-q

56) Awad HA, Halvorsen YD, Gimble JM, Guilak F. Effects of transforming growth factor beta1 and dexamethasone on the growth and chondrogenic differentiation of adipose-derived stromal cells. Tissue Eng. 2003 Dec;9(6):1301-12. DOI:
10.1089/10763270360728215 PMID:14670117.

57) Harriman GR, Bogue M, Rogers $P$, Finegold M, Pacheco S, Bradley A, et al : Targeted deletion of the IgA constant region in mice leads to IgA deficiency with alterations in expression of other Ig isotypes. J Immunol. 1999 Mar;162(5):2521-9. PMID: 10072491.

58) Sakuma T, Matsumoto T, Kano K, Fukuda N, Obinata $\mathrm{D}$, Yamaguchi $\mathrm{K}$, et al. Mature, adipocyte derived, dedifferentiated fat cells can differentiate into smooth muscle-like cells and contribute to bladder tissue regeneration. J Urol. 2009 Jul;182(1):355-65. DOI: 10.1016/j.juro.2009.02.103 PMID:19457498.

59) LendeckelS, Jodicke A, Christophis P, Heidinger K, Wolff J, Fraser JK, et al. Autologous stem cells (adipose) and fibrin glue used to treat widespread traumatic calvarial defects: case report. J Cranio maxillofac Surg. 2004 Dec;32(6):370-3. DOI:10.1016/j.jcms.2004.06.002 PMID:15555520.

60) Thesleff $T$, Lehtimaki $K$, Niskakangas $T$, Mannerstrom B, Miettinen S, Suuronen R et al. Cranioplasty with adipose-derived stem cells and biomaterial: a novel method for cranial reconstruction. Neurosurgery. 2011;68(6):1535-1540.DOI:10.1227/ NEU.0b013e31820ee24e PMID:21336223.

61) Mizuno H, Zuk PA, Zhu M, Lorenz HP, Benhaim P, Hedrick MH. Myogenic differentiation by human processed lipoaspirate cells. Plast Reconstr Surg 2002. Jan;109(1):199-209. DOI: 10.1097/00006534200201000-00030 PMID:11786812.

62) Owens GK, Kumar MS, Wamhoff BR. Molecular regulation of vascular smooth muscle cell differentiation in development and disease. Physiol Rev. 2004 Jul;84(3):767-801. DOI: 10.1152/ physrev.00041.2003

63) Shanahan CM, Weissberg PL, Metcalfe JC. Isolation of gene markers of differentiated and proliferating vascular smooth muscle cells. Circ Res. 1993 Jul;73(1):193-. DOI: 10.1161/01.RES.73.1.193

64) Beamish JA, He P, Kottke-Marchant K, Marchant RE. Molecular regulation of contractile smooth muscle cell phenotype: implications for vascular tissue engineering. Tissue Eng Part B Rev. 2010;16(5):467. DOI: $10.1089 /$ ten.teb.2009.0630

65) Venkataiah VS, Handa K, Njuguna MM, Hasegawa T, Maruyama K, Nemoto E etal. Periodontal Regeneration by Allogeneic Transplantation of Adipose Tissue Derived Multi-Lineage Progenitor Stem Cells in vivo. Sci Rep. 2019 Jan;9(1):921. DOI: 10.1038/s41598018-37528-0 
66) Wang J, Zhang R, Shen Y, Xhu C, Qi S, Lu L, et al. Recent advances in cell sheet technology for periodontal regeneration. Curr Stem Cell Res Ther. 2014;9(3):162. DOI: $10.2174 / 1574888 X 09666140213150218$

67) Zhang H, Liu S, Zhu B, Xu Q, Ding Y, Jin Y. Composite cell sheet for periodontal regeneration: crosstalk between different types of MSCs in cell sheet facilitates complex periodontal-like tissue regeneration. Stem Cell Res Ther. 2016;7(1):168. DOI: 10.1186/s13287-016-0417-x

68) Baba, S, Yamada Y, Komuro A, Yotsui Y, Umeda M, Shimuzutani $\mathrm{K}$ et al. Phase I/II trial of autologous bone marrow stem cell transplantation with a threedimensional woven-fabric scaffold for periodontitis. Stem cells int. 2016:1-7. DOI: 10.1155/2016/6205910

69) Zhang J, Huang X, Wang H, Liu X, Zhang T, Wang Y, et al. The challenges and promises of allogeneic mesenchymal stem cells for use as a cell-based therapy. Stem Cell Res Ther. 2015;6:234. DOI: 10.1186/s13287-015-0240-9

70) Tsumanuma Y, Iwata T, Kinoshita A, Washio K, Yoshida $\mathrm{T}$, Yamada A, et al: Allogeneic transplantation of periodontal ligament-derived multipotent mesenchymal stromal cell sheets in canine critical-size supra-alveolar periodontal defect model. Bio Research open access. 2016;5(1):22-36. DOI: 10.1089/biores.2015.0043 